Article

DAĞHAN IRAK ${ }^{\#}$

Sciences Po Paris, France

\title{
KURDISH IDENTITY AND SPORTS IN TURKEY: THE CASE OF AMEDSPOR
}

\begin{abstract}
The Kurds, the largest minority in Turkey, have almost no visibility in Turkish sports. While Kurdish sportspeople are not discouraged from joining sport activities, their participation is heavily monitored by the government agencies against any manifestation of ethnic identity. Football in Kurdish regions, seen by the Turkish state as a tool to distract Kurdish youth from political activities, has always been subjected to the direct intervention of the civil and military bureaucracy, their presence in club boards is not uncommon. However, a third-division club, named Amedspor, challenged all the unwritten rules related to Kurds in sport, at the expense of receiving recurring suspension from the Turkish Football Federation. This article examines Kurdish sport and the Amedspor case through Manuel Castells' conception of legitimizing, resistance and project identities.
\end{abstract}

Keywords: Turkey, football, identity, Kurds, resistance

" Corresponding author: Sciences Po Médialab, 27 rue Saint-Guillaume 75337 Paris cedex 07 France.

E-mail: daghan.irak@sciencespo.fr 


\section{Introduction}

The Kurds in Turkey have a unique situation as a minority, since they are considered to be a "founding component" of the Turkish Republic, in a similar status with the Turks, in the official discourse; however there is a century-long history of them being deprived from social, political and cultural rights (Cizre Sakallıoglu 1996: 8). Since the 1980s, there has been a violent conflict between the Turkish state and the Kurdish political movement, having resulted in the deaths of soldiers, guerrillas and thousands of civilians. After a failed negotiation process between two parties in 2009-2015, the Kurdish-Turkish issue has reached a new bloody climax as the Turkish government led by Recep Tayyip Erdoğan embraced an ultra-nationalistic and openly anti-Kurdish stance (Özpek 2018: 55) that led to the imprisonment of thousands of Kurdish politicians, journalists and lawyers, and also helped Erdoğan's Justice and Development Party (AKP) to form an alliance with the ultra-nationalist Nationalist Movement Party (MHP) to keep itself over the 50\% threshold in the upcoming presidential ballot that would practically open Erdoğan the gates of a one-man rule. Especially after the failed coup d'etat of July 2016 that had no ties whatsoever to the Kurdish Political Movement (KPM), the AKP government used the State of Emergency declared right after the coup to suppress the Kurdish political institutions and the Kurdish civil society in general. (Celep 2018: 20-21)

Kurdish sports had its share of the increasingly autocratic political climate of Turkey, as the elected mayors of Kurdish towns of the Peace and Democracy Party (BDP - the legal representative of the Kurdish political movement in the region), who were providing financial support to local clubs, have been mostly arrested and one by one replaced by government-appointed trustees. (Celep 2018: 21) As most clubs are tied to the municipalities, their financial flow went into direct government control. Also, two local clubs 73 Cizrespor and Şırnak Belediye Spor Kulübü were shut down by government decrees in January 2017.

Among the Kurdish clubs, Amedspor, former club of the Diyarbakır municipality run by the BDP (renamed later to DBP, Democratic Regions' Party), is a noteworthy example. After the 2. lig (third division) club Diyarbakır Büyükşehir Belediyespor (the municipality club) changed its name to Kurdish name of the city (Amed) and colors to Kurdish national colors, it started receiving penalties and suspensions in weekly basis from the Turkish Football Federation (TFF), its fans were frequently blocked from the away games and its star player, former St. Pauli forward, Deniz Naki was suspended from football for life and put in trial for "supporting terrorism." Despite severe pressure, Amedspor played in the quarter finals of the Turkish Cup in the 2015-16 season and pulled a surprise 3-3 draw against Fenerbahçe at home, and in 2016-17, came close to be promoted to the Second Division (1.Lig). The club's women's section was also promoted to the top division of the Turkish women's football leagues. 
In this article, we will try to analyze the Kurdish sports in Turkey and the Amedspor case through the dichotomy of identities conceptualized by Manuel Castells, based on forms and origins of identity building; namely legitimizing, resistance and project identities (2010:8), through the historical course of events concerning the Kurdish political movement, as well as the Kurdish football. The legitimizing identity is introduced by the dominant institution of society, the resistance identity is created by the dominated to contest the dominating power, and the project identity aims to redefine the position of the concerned actors in society. (Castells 2010:8)

\section{The Kurdish Question: legitimizing, resistance and pro- ject identities}

Castells' proposed distinction on identity building investigates the appearance of different identities in social actors in three different categories that generate different types of social structures. The legitimizing identity, which is "introduced by the dominant institutions of society to extend and rationalize their domination vis à vis social actors," according to Castells, generates a civil society comprised of different organizations and institutions, "as well as a series of structured and organized social actors." (Castells 2010:8) Castells (2010: 70) argues that this type of identities is in crisis, since the civil society of the industrial era and the nation-states tend to disintegrate, in the network society. This argument is more open to discussion that the period that it was claimed, since it seems now possible that nation-states in the network society era may be able to reproduced in a global context, as right-wing populism that considers people as nations has successfully adapted itself to the new communication strategies of the network society (Ernst et al. 2017:12), as in the use of social media platforms that "allow people to communicate their identity beyond the immediate range of social interactions, and, therefore, in a more selective and stylized manner." (Krämer 2017:10) In our case, the domination of the Turkish state over its Kurdish citizens with its institutions and imposed identity is ever-present. It may be argued that the failed peace negotiation process of the early 2010 s might have been affected by Turkey's loosening from its confinement of its state-centric nationalism triggered by the globalization and the country's accession process to the European Union. (Keyman 2016:77-78) However, it should be also noted that the peace process that could have been of vital importance in the history of Turkey was merely dispensable for Erdoğan, since he decided to end the process and take a hard line of populist ultra-nationalism with heavy anti-Kurdish and militaristic undertones, mostly to "win back the support that it had lost to the MHP [Nationalist Action Party] in the June 2015 elections. (Sayar1 2016: 272) The vulnerability of the peace process and less nationalistic official policies came from the durability of Turkey's century-long practices of creating and preserving dominant institutions to extend and consolidate its domination. It may also be 
claimed that Erdoğan's twist to the right-wing populism, that he embraced after he completely lost his credibility vis-à-vis Europe after the brutal repression of the mass protests in 2013, and he was openly contested in domestic politics by the Kurdish leadership, is in line with the rise of the right-wing populism in Europe which aims to disrupt the European democratic institutions and put the idea of democracy itself under question. Therefore, Turkey's imposing a legitimizing identity to the Kurds, except a brief period that resulted in utter failure, is not curbed by the rise of the network society; it has been slightly altered.

The legitimizing identity imposed by the Turkish state to the Kurds, despite marginally changing from time to time, entails denouncing all sorts of identity politics and the claims of cultural and political rights other than offered by the Turkish state. In other words, Kurds in Turkey are free to live as Kurds privately, as long as they accept to be Turks publicly, under the imposed non-negotiable conditions that define the set of rights and liberties that the Kurds are entitled to, which may will be lesser than those given to ethnic Turks. Navaro-Yashin (2002:53) claims that hostility towards Kurds' cultural claims is shared notably by the secularist Turks who believe that "the Turkish state was created for them." It is interesting that Islamist Erdoğan's switch to anti-Kurd nationalism with a similar hostility that had also been used against the Islamists for decades is fully embraced by his electoral base. This may be explained by the Islamists' new-found penchant to use the traditional weapons of the state that they have taken over, as well as the KPM being the only political power that can tip the scales against the AKP's favors, as the HDP did in the June 2015 elections which almost cost the AKP the government and was immediately followed by the military operations against Kurds and mass incarcerations of the HDP and the BDP members.

This hostile feeling against Kurds is fuelled by the dominant official and social perceptions of Kurds in Turkey; which have included logic that justify assimilation considering Kurds as "future Turks" (Ergin 2014:327), "pseudo-citizens" (Yegen 2009: 610-612), or "exclusive recognition... [that] targets Kurdish migrants exclusively" (Saracoğlu 2009: 642-643) which recognizes the Kurds as the "recognized other... distinguished by negative traits" (ibid.: 642). Therefore, the Kurds, with or without accepting the norms imposed to them are prone to be excluded, which inevitably brings out the second form of identity building, according to Castells' conception, the resistance identities.

The resistance identity is "generated by those actors who are in positions/conditions devalued and/or stigmatized by the logic of domination, thus building trenches of resistance and survival on the basis of principles different from, or opposed to, those permeating the institutions of society." (Castells op.cit.:7) Castells depends on Calhoun while formulating this identity, who in turn defines identity through the "interrelated problems of self-recognition and recognition by others." (Calhoun 1994: 20) According to Calhoun, identity politics that stem from these problems are political, "because they involve refusing, diminishing or displacing identities others wish to recognize in individuals." (Calhoun 1994: 21)

Historically, since the emergence of the KPM in the 1960s as a component of 
the popular radical-left movements of the era, it has always represented a resistance identity in multiple degrees. According to Bozarslan, behind the rebirth of Kurdish nationalism in the late 1950s and the early 1960s, there was the experiment in political pluralism, "a relatively little known combination of collective memory and a tradition of rebelliousness," and the new Kurdish intelligentsia influenced by left-wing politics. (1992: 75) Yavuz (2001: 9-10) argues that the movement appeared as an attempt to secularize the Kurdish question which had been traditionally tied to the religious identities and leaderships, depending on "the right of nations to self-determination," a discussion originally started by Lenin in Marxist circles in 1914, to take the Kurdish Question into the agenda of the left-wing politics in Turkey. The affinity of the Kurdish intellectuals of the 1960 s and the 1970s to Marxism and modernism in general, inevitably created a tense relationship with the religious elders, comparable to the relationship between the pioneers of the Greek enlightenment in the early $19^{\text {th }}$ century and the Greek-Orthodox religious leadership. In a way, it was the Kurdish enlightenment that started, embracing a resistance identity against the old social structures and leaderships of the Kurds.

The oppression against the Kurdish identity after the 1980 coup reinforced a higher layer of resistance identity, against the Turkish state. This identity rapidly rose to prominence as the Kurdistan Workers' Party (PKK) led by Abdullah Öcalan, a former Ankara University student and leftist militant of the 1970s, launched an armed campaign against Turkish military and civilian targets. As the war between the PKK and the Turkish Army escalated, the repression over the Kurdish people was aggravated, led to village displacements and a wave of Kurds taking shelter in Turkish cities, which triggered permanent collective memories in Kurds (van Bruinessen 2005: 51), as well as a daily dose of social exclusion in the places that they migrated. All these resulted in a more identity-conscious generation which embraced the resistance identity to survive. Van Bruinessen confirms this inference while explaining the growing popularity of the PKK among Kurds at that period; "The armed conflict has increased the Kurds' awareness of their distinct ethnic identity and caused an acute sense of being regarded as second-class citizens at best. Since all moderate spokespersons for the Kurds have been treated with scorn or have been jailed by the authorities, many have come to see the PKK as the only force that can represent them" (1998: 49). The PKK's role as the representative of the Kurdish resistance identity was later partially undertaken by a line of Kurdish political parties that found ways to circumvent political restrictions against the KPM to voice Kurdish concerns in the Parliament. The BDP and the HDP are current political parties that represent the KPM respectively in local and national level.

While the claims of the KPM have varied depending on the period, from independence, to equal citizenship, to democratic autonomy; since its beginning, its core claim has been the recognition and the acceptance of the Kurdish identity by the Turkish state and society. As Calhoun (op.cit.: 21) states, identity politics are public and collective, "they involve seeking recognition, legitimacy 
(and sometimes power), not only expression or autonomy; other people, groups and organizations (including states) are called upon to respond." Therefore, the ultimate destination of all resistance identities, including the Kurdish one, may be considered to be a durable change in the current power structure of the social actors, which is conceptualized by Castells as the project identity.

Castells explains the project identity as; "when social actors, on the basis of whatever cultural materials are available to them, build a new identity that redefines their position in society and, by so doing, seek the transformation of overall social structure" (op.cit.: 7). For the Kurdish case, it may be debated when it transformed to a project identity, since it has had varying political claims through the course of time that demanded durable political status. However, in our view, the "Democratic Autonomy Project" that was first pronounced in the 2007 congress of the now-defunct Democratic Society Party (DTP, predecessor of the BDP-HDP) represents the transformation between the resistance identity and the project identity. The concept which had its roots in Abdullah Öcalan's defence in court in 1999, was later introduced in 2005 as "democratic confederalism" to the Kurdish political circles. (Gürer 2015: 59-60) Ersanlı and Bayhan's analysis of the project reveals the transformation from the resistance identity to the project identity; "The perceptions of communities that claim the right to self-determination and especially those of intellectuals have changed regarding nations and states. As in Turkey and many other countries, not claiming a state (see the DTP, BDP leaflets and the DTK [Democratic Society Congress] draft text) is possible, and it is foreseeable that the welfare of the peoples may be reached by a stateless resolution, namely by autonomy." (2012: 226-227) The difference of the "Democratic Autonomy Project" from previous political claims of the $\mathrm{KPM}$ is, as pertinent to the definition of the project identity, it aims to transform the entire social structure in Turkey (as it proposes autonomous regions all over the country), by redefining the Kurds' position (giving them autonomy). The project, according to Akkaya and Jongerden, "involves an active agency in the form of a force of struggle" where "the state is not the main frame of reference in democratic confederalism, demands or expectations are not directed to the state, but shaped in the daily lives by people themselves." (2013: 198-199)

The "Democratic Autonomy Project" and the peace negotiations with the Turkish state may also be interpreted as the transformation of the legitimizing identity by a project identity. One might compare this project with other nationalist dilemmas; such as Britain-Scotland, Yugoslavia-Croatia or Iraq-Kurdistan. Nairn (2003: 204) classifies these dilemmas in two categories; "under-developed or pillaged regions that have finally begun to react against this treatment; and quite highly-developed epicentres of industrialization, middle-class cultures who are for one reason or another out of phase with the ruling nation-state, and want separate development to get ahead faster." The Kurdish case in Turkey (as opposed to the Kurdish case in Iraq, according to Nairn (ibid)) is an example of the first category; the Kurdish regions in Turkey have been systematically impoverished, and the emergence of a Kurdish economic capital has been pre- 
vented by moves like the liquidation of Doğu Bank, the Kurdish bank, by a military decree in 1960. (Bozarslan, op. cit.: 80) In these conditions, the Kurdish movement was reborn as a cultural-political movement in connection with the Turkish left (ibid.: 78-80), and then partly transformed into an armed struggle in the early 1980s. The secular-left Kurdish political movement, from the beginning, contested the feudal structures in the region "who were considered to be as responsible as the Turkish bourgeoisie for problems faced by the community" (Bozarslan, op. cit.: 77-78). Therefore, in a setting without industrialization or a bourgeoisie but with an intelligentsia, the Kurdish political movement has been marked by a heavy emphasis on the ethno-cultural identity, which is needed to "translate regional economic disparities into a nationalist movement," as Yavuz underlines. (op. cit.: 22)

In regards to Amedspor, it is also important to note that the Amedspor name change and its appearance as an identity club took place in October 2014, after the democratic autonomy was presented as the "minimal prerequisite" in the BDP manifesto (Milliyet 23 January 2014) for the March 2014 elections where the BDP recorded a major victory in the Kurdish cities against the AKP candidates in the local elections of 2014, including the 55,1 to $35 \%$ victory in Diyarbakır. Even though, the name change cannot be directly associated with the project, it is also impossible to dissociate from it, since, as we will try to argue, the Amedspor project shares with the KPM similar objectives of a project identity in its own domain.

\section{Football clubs representing sub-state ethnic identities}

Representation of sub-state ethnic identities through sports, especially football, is not a new phenomenon. It has worldwide-known examples such as Athletic Bilbao representing the Basques and FC Barcelona the Catalans in Spain, or less-known examples like the Arab football club in Israel or the Armenian clubs in Iran, such as FC Ararat Tehran. The relationships of sub-state nations' football teams with the states they live under can be analysed through recognition; the way they relate themselves to the state, and the way the state relates to them, in a way overlapping Calhoun's formulation of the role of recognition in identity formation.

Regarding the way minority ethnic clubs position themselves vis-a-vis the institutional structure imposed by the sovereign state; Sorek, working on Arab football teams in Israel, presents a very fruitful distinction of three ideal types of institutional strategies. According to the author (Sorek 2003: 426-427); the first type is the cultural distinction strategy, in which the group develops or adopts a particular sports field; the second type is structural separation, in which the group establishes its own governing bodies for sports; and the third type is intensive inclusion, which takes the most popular sports of the majority. As in most examples, like the Arab teams in Israel, minority teams in Sweden, Germany, Canada and Australia, or the Austrian teams in Nazi Germany; Amedspor 
also represents the third type in which the Kurdish teams join Turkish football leagues to represent the sub-state ethnic identity. One reason for the third option to be popular may be the fact that competing in state competitions provide some kind of limited recognition which also constitute contestation. This contestation appears in two different aspects; sportively as representation also means challenging rival teams, and culturally as teams may display national or ethnic symbols and slogans. In the Amedspor example, both aspects are present; Amedspor's away win against Bursaspor in front of notoriously ultra-nationalistic Bursa fans in the Turkish Cup is undeniably emblematic, as well as Amed fans chanting "children should not die, they should come to our matches" or "Resist Diyarbakır, Resist Amed" making references to the Turkish military operations in Diyarbakır having resulted in dozens' of civilian deaths. Even the use of the name Amed in the club's name is a direct contestation of official state policies, as Turkish state and the nationalists consistently reject the use of Diyarbakır's name in Kurdish language.

In reference to Castells' conception of identities, Spaaij and Viñas (2013: 188) claim that the "(...) politics of contestation rests on the notion of diverse and oppositional value systems within football and involves a combination of resistance and project identities." Therefore, the contestation manifested by the football clubs representing sub-state ethnic identities should be observed in relation to resistance and project identities.

\section{A brief history of Kurdish football}

The exact date of football's arrival in the city of Diyarbakır remains to be unknown. However, it is quite likely to have happened after the end of the Turkish War of Independence in 1923 and before the foundation of Ayspor club in 1930. The first record of national football in Diyarbakır is the inclusion of the city in the National Championship's Mersin Round Robin games in 1932. (Yüce 2014: 251) In 1933, it is recorded that Ayspor reached the Diyarbakır city championship, beating Yildızspor. As Yüce, the author of the most intensive sources on football in the 1930s in Turkey, underlines the names of two major clubs in Diyarbakır is striking, since Ay and Yıldiz respectively mean "crescent" and "star," the symbols of Turkish nationalism. (Yüce 2014: 263) As these clubs were evidently founded well before the establishment railway connection of Diyarbakır to the rest of the country in 1935 , we may speculate with caution that both these clubs bearing symbols of Turkish nationalism may be founded at least by the encouragement of the military deployed in Diyarbakır. One other evidence supporting that claim is the other clubs joining the Diyarbakır City League in 1940-41; Kolordu (Army Corps), Tayyare (Airforce), and Muhabere (Communications) (ibid.: 380). Also, Yüce states that all the clubs joining the league in neighboring Maras League in 1944 are army teams. (ibid.: 417) Therefore, it is safe to say that football activities in the regions are pioneered by the military, however we are unable to say if this was simply some leisure activity for the army members or a policy to integrate the 
region to the newly-founded republic. On the other hand, the latter option seems unlikely as individual athletic activities were prioritized over team sports at that period by the state, and football was not used to ensure national unity. As a matter of fact, football was feared to be a perturbation for Turkish nationalism because of the fierce rivalries it featured.

Professional football in Diyarbakır starts with the 1960s, like in most Anatolian cities, as a result of an initiative led by Orhan Şeref Apak, the President of the TFF of the period. (Gökaçt 2008: 222-226) It should be noted that this expansion of professional football to Anatolian cities is a consequence of Turkish football's transformation in the previous decade. In the 1950s, as full professionalism was accepted, the neighborhood clubs of Istanbul, the grassroots of Turkish football were destined to financial collapse as they could not cope with the new demands of the football scene with their limited budgets and fan bases. Also, the removal of last remaining minority bourgeoisie by the deportation of Greek nationals and their (mostly Turkish national) families starting from the late 1950s was the death sentence of minority clubs such as Beyoğluspor, the successor of famous Pera Club which also gave birth to two major clubs, AEK and PAOK, in Greece. By the 1960s, football clubs except the "Three Giants" of Istanbul were insignificant details, which led to the collapse of the national team that was previously qualified for the World Cup in 1954. The expansion of professional football to provincial Anatolia and the establishment of lower divisions was an obligation for football's sustainability in Turkey. The TFF and the other state agencies handled this task with a pretty much hands-on approach, in cooperation with governors of the cities, mayors, bank managers or wealthy businesspeople. Diyarbakırspor's story is not any different. The club was founded in 1968, by Diyarbakır mayor Nejat Cemiloğlu's efforts, and merging two most popular amateur clubs, Dicle Gençlik and Yıldız Spor. In Diyarbakırspor's foundation, many prominent figures of the city joined their forces, and the club was embraced by the whole city. (Arhan 2001: 28) The club is an example of political and business elite cooperation in provincial football clubs, however unlike many examples in other cities usually dominated by the "Three Giants" regarding fan base, popular support for Diyarbakırspor is also present.

It should also be noted that the foundation years of Diyarbakırspor coincide with the emergence of Kurdish intelligentsia who will generate the Kurdish Political Movement. In Diyarbakırspor's early years, the KPM does not engage with the club despite its popularity. This reluctance can be explained by the left's critical stance towards football in the 1970s in Turkey, of which the KPM was part of. According to Bostancioğlu (2004: 242), the socialists in Turkey considered football to be a tool used for manipulating and stupefying the people. On the other hand, the increasing number of political murders in Diyarbakır in the late 1970s affected Diyarbakırspor, as the attention the club attracted decreased, despite its success in the First Division. (Arhan op.cit: 33) This period also led to an estrangement between the club and the city, as Turkish nationalist Çelebi Eser took over the club. This feeling that resulted in Diyarbakırspor being left 
alone, further accelerated during the junta years after the 1980 coup d'état as the people of Diyarbakır and the members of the KPM were subject to severe torture, and football was hardly a priority.

In 1999, the Kurdish question took a massive turn as the PKK leader Abdullah Öcalan was captured in Kenya and brought to Turkey by the Turkish Armed Forces. Öcalan's declaration of "Democratic Republic Project" in capture reduced the armed clashes in Kurdish region, and both parties of the conflict changed strategies, shifting to non-violent struggle. The Turkish government aimed to reduce the KPM's dominance in the region by taking some economic and social measures. Football, more precisely promoting Diyarbakırspor to the top division, appeared to be one of these measures. Gaffar Okkan, the police chief in the city led this initiative, also controlling the club by registering 700 police officers to the club, thus holding a massive voting power inside Diyarbakırspor. (ibid.: 51) Okkan, a very popular figure in Diyarbakır due to his community-based approach, believed Diyarbakırspor's promotion to the top division was a powerful tool to reduce the KPM's influence in the city. His strategy was also supported by the governors and the non-KPM MPs of the region.

In January 2001, while Diyarbakırspor was on the verge of being promoted, Gaffar Okkan was assassinated at point-blank range, as well as five other police officers. The culprits were never founded and no political movement claimed responsibility to the murder, while Hezbollah was generally considered to be behind the assassination. After Okkan's death, Diyarbakırspor's promotion was perceived as a promise to the murdered police official, not only by the Diyarbakırspor fans but also the politicians nationwide. The club meanwhile won its games under shady conditions. The Altay playoff game, in which the TV broadcast was canceled, the opponent players were violently attacked in and off the pitch. The referees openly enabled Diyarbakırspor to win the game, and the referee observers graded the referees by $9 / 10$. Intriguingly, all but one of the referees and observers appointed to the game were either military or police officers, while one observer Galip Bitigen had even served as a military officer in Diyarbakır for five years. (ibid.: 68)

The particularity of the situation of Kurds in Turkey regarding sports activities is that, they have never been actively discouraged by the Turkish state to be involved. On the contrary, as we tried to show, sports, especially football in the Kurdish regions, was considered by the civil and military bureaucracy as a way of depoliticizing the Kurdish youth and diverting them from the Kurdish political movement, especially from the PKK. Therefore, the leading civil and military bureaucratic actors in Kurdish cities played an important role in the rise of sports clubs in the region to prominence.

While the football in Turkey has always been under state and financial elites' tight supervision, the control over the football scene in the Kurdish region of the country has been even more rigid. While the region's teams were rarely represented in the top division, their occasional success almost always came when the teams were direct ruled by state officials. Apart from Diyarbakırspor, 
Vanspor, in the 1990s, was promoted to the top division with huge support from governor Mahmut Yilbaş, who even tried to revoke relegation during his term in parliament to prevent team going back to the Second Division (Milliyet 13 April 1998). State officials considered football in Kurdish regions to be an antidote against "terror," a term very liberally used in Turkey against almost all ethnic political activities, other than Turks'. Therefore, even though Kurdish cities' teams appeared in the Super League from time to time, their supporters had absolutely no chance of displaying their Kurdish identity in the stands. The only time their Kurdishness were remembered was when opponent fans treated them as if they were PKK members, like Bursaspor's ultra-nationalist fans called Diyarbakırspor fans as such in 2009. This situation changed when the state officials considered sponsoring football teams against Kurdish separatist movements to be a failure and withdrew from club boards in the late 2000s. Most teams faced bankruptcy, including Vanspor and Diyarbakırspor, and plummeted into lower leagues. Meanwhile, the KPM-run municipalities in the region started to support the local teams. Their involvement in sports clubs triggered a very rapid politicization, as politically-engaged fans who were not into city teams before also embraced the new initiatives.

\section{The curious case of Amedspor}

Diyarbakır Büyükşehir Belediyespor (the team of the municipality in Diyarbakır) was one of the clubs sponsored by the KPM-run municipalities. In 1999, the Municipality of Diyarbakır was reclaimed by DEHAP (Democratic People's Party) of the Kurdish Political Movement (KPM) by $50 \%$ of votes, and the team was affiliated to city's water administration DİSKI to provide financial support. In this period, the club regained recognition in Diyarbakır, alongside the city's principal and state-endorsed club Diyarbakırspor. In 2014, during Turkish government's "Kurdish opening," a set of reforms including further cultural rights for minorities and the peaceful resolution of the Kurdish issue, the club changed its name to Amedspor, which was later amended officially as Amed Sportif (still commonly called Amedspor) since the TFF rejected the name citing a defunct amateur club with the same name. The club also attempted to use green-red-yellow, the colors of the KPM, as its official colors; but due to political challenges they settled with green-red-white, less controversial colors in Turkey, though being the colors of the Kurdistan flag. Meanwhile, in June 2015, the Peoples' Democratic Party (Halkların Demokratik Partisi - HDP, the representative of the KPM in non-Kurdish regions) launched a successful election campaign directly contesting Recep Tayyip Erdoğan's iron-hand presidency ambitions with the slogan "We won't let you be the President," acquiring 13,1\% of votes nationwide, exceeding comfortably both the national threshold and all previous election results of the KPM. The HDP appearing as a nationwide radical-left option against Erdoğan's rule resulted in the "Kurdish opening" being discarded by the latter, and the government launched a series of military operations along 
with month-long curfews resulting in dozens in civilian deaths (OHCHR 2017; İHD 2016; EuroMed Rights 2016). When Amedspor kicked off its historic 2015-16 campaign which would take them to the quarter finals of the Turkish Cup against giants Fenerbahçe, the emblematic Suriçi neighborhood of the city was under siege, leaving many historical building in ruins.

Table 1 - Suspensions and penalties given to Amedspor by the TFF between 2015-2018.

\begin{tabular}{|c|c|c|c|c|}
\hline Date & Actor & Reason & Suspension & Penalty \\
\hline $10 / 01 / 2015$ & Coach Sertaç Küçükbayrak & Unsportmanship & 2 matches & $6000 \mathrm{TL}$ \\
\hline $10 / 08 / 2015$ & Fans & Disorder & & $5000 \mathrm{TL}$ \\
\hline $12 / 08 / 2015$ & Team & Unsportmanship & & $2500 \mathrm{TL}$ \\
\hline $17 / 09 / 2015$ & Player Sercan Özçelik & Violence & 2 matches & $2000 \mathrm{TL}$ \\
\hline $29 / 09 / 2015$ & Fans & Ideological Propaganda & & $20000 \mathrm{TL}$ \\
\hline $17 / 11 / 2015$ & Fans & Swearing & & Warning \\
\hline $19 / 11 / 2015$ & Fans & Ideological Propaganda & & $20000 \mathrm{TL}$ \\
\hline $17 / 12 / 2015$ & Fans & Disorder & & $5000 \mathrm{TL}$ \\
\hline $17 / 12 / 2015$ & Fans & Swearing & & Warning \\
\hline $29 / 12 / 2015$ & Fans & Disorder & & $10000 \mathrm{TL}$ \\
\hline $29 / 12 / 2015$ & Fans & Ideological Propaganda & & $20000 \mathrm{TL}$ \\
\hline $29 / 12 / 2015$ & Fans & Swearing & & Warning \\
\hline $12 / 01 / 2016$ & Fans & Disorder & & $5000 \mathrm{TL}$ \\
\hline $12 / 01 / 2016$ & Fans & Swearing & & $8000 \mathrm{TL}$ \\
\hline $14 / 01 / 2016$ & Fans & Ideological Propaganda & & $40000 \mathrm{TL}$ \\
\hline $19 / 01 / 2016$ & Fans & Disorder & 1 match & \\
\hline $19 / 01 / 2016$ & Fans & Ideological Propaganda & & $40000 \mathrm{TL}$ \\
\hline $19 / 01 / 2016$ & Fans & Swearing & & $5000 \mathrm{TL}$ \\
\hline $02 / 02 / 2016$ & Fans & Disorder & & $5000 \mathrm{TL}$ \\
\hline $02 / 02 / 2016$ & Fans & Ideological Propaganda & 1 match & $20000 \mathrm{TL}$ \\
\hline $02 / 02 / 2016$ & Fans & Swearing & & Warning \\
\hline $16 / 02 / 2016$ & Team & Unauthorized Banner & & $5000 \mathrm{TL}$ \\
\hline $23 / 02 / 2016$ & Coach Faruk Türk & Insulting the Referee & 1 match & $3000 \mathrm{TL}$ \\
\hline $23 / 02 / 2016$ & Technical Director Harun Kılıç & Insulting the Referee & 3 matches & $3000 \mathrm{TL}$ \\
\hline $03 / 03 / 2016$ & Player Tekin Adar & Violence & 4 matches & $6000 \mathrm{TL}$ \\
\hline $02 / 04 / 2016$ & Player Deniz Naki & Ideological Propaganda & 12 matches & $19500 \mathrm{TL}$ \\
\hline $21 / 04 / 2016$ & Fans & Disorder & & $7500 \mathrm{TL}$ \\
\hline $21 / 04 / 2016$ & Fans & Ideological Propaganda & -3 points & $40000 \mathrm{TL}$ \\
\hline $21 / 04 / 2016$ & Fans & Swearing & & $8000 \mathrm{TL}$ \\
\hline $04 / 07 / 2016$ & Fans & Swearing & & $4000 \mathrm{TL}$ \\
\hline $03 / 08 / 2016$ & Board member Emrullah Gürbüz & Disorder & 50 days & $10000 \mathrm{TL}$ \\
\hline $03 / 08 / 2016$ & Team & Unsportmanship & & $2100 \mathrm{TL}$ \\
\hline $18 / 08 / 2016$ & Player Abdullah Çetin & Unsportmanship & 6 matches & $13000 \mathrm{TL}$ \\
\hline $29 / 09 / 2016$ & Club & Security Measures & & $8000 \mathrm{TL}$ \\
\hline $29 / 09 / 2016$ & Fans & Swearing & Warning & \\
\hline $29 / 09 / 2016$ & Club & Unauthorized Entry & & $13000 \mathrm{TL}$ \\
\hline $11 / 10 / 2016$ & Fans & Swearing & & $4000 \mathrm{TL}$ \\
\hline $15 / 12 / 2016$ & Fans & Disorder & & $5000 \mathrm{TL}$ \\
\hline $15 / 12 / 2016$ & Player Deniz Naki & Unsportmanship & 4 matches & $2100 \mathrm{TL}$ \\
\hline $20 / 12 / 2016$ & Fans & Ideological Propaganda & & $40000 \mathrm{TL}$ \\
\hline $17 / 01 / 2017$ & Fans & Swearing & & Warning \\
\hline $02 / 02 / 2017$ & Fans & Disorder & & $10000 \mathrm{TL}$ \\
\hline $23 / 02 / 2017$ & Team & Unsportmanship & & $2100 \mathrm{TL}$ \\
\hline $23 / 03 / 2017$ & Fans & Disorder & & $15000 \mathrm{TL}$ \\
\hline $23 / 03 / 2017$ & Club & Security Measures & & $14000 \mathrm{TL}$ \\
\hline $23 / 03 / 2017$ & Fans & Swearing & & $12000 \mathrm{TL}$ \\
\hline $23 / 03 / 2017$ & Club & Unauthorized Entry & & $13000 \mathrm{TL}$ \\
\hline $23 / 03 / 2017$ & Player Deniz Naki & Unsportmanship & 6 matches & $7500 \mathrm{TL}$ \\
\hline $20 / 04 / 2017$ & Fans & Ideological Propaganda & & $40000 \mathrm{TL}$ \\
\hline $20 / 04 / 2017$ & Club & Security Measures & & $5000 \mathrm{TL}$ \\
\hline $23 / 05 / 2017$ & Fans & Disorder & & $15000 \mathrm{TL}$ \\
\hline $23 / 05 / 2017$ & Fans & Swearing & 1 match & $3000 \mathrm{TL}$ \\
\hline $23 / 05 / 2017$ & Player Okan Dernek & Violence & 3 matches & $1800 \mathrm{TL}$ \\
\hline $21 / 09 / 2017$ & Team & Unauthorized Apparel & & Warning \\
\hline $28 / 09 / 2017$ & Club & Improper Equipment & & $5000 \mathrm{TL}$ \\
\hline $28 / 09 / 2017$ & Club & Improper Equipment & & $5000 \mathrm{TL}$ \\
\hline $16 / 11 / 2017$ & Fans & Disorder & & $5000 \mathrm{TL}$ \\
\hline $16 / 11 / 2017$ & President Nurullah Edemen & Insulting the Referee & 3 months & $30000 \mathrm{TL}$ \\
\hline $23 / 11 / 2017$ & Fans & Disorder & & $5000 \mathrm{TL}$ \\
\hline $02 / 01 / 2018$ & Club & Not playing the match & -3 points & \\
\hline $30 / 01 / 2018$ & Player Deniz Naki & Ideological Propaganda & Lifetime & $273000 \mathrm{TL}$ \\
\hline $15 / 03 / 2018$ & Fans & Swearing & & Warning \\
\hline
\end{tabular}


Simultaneously, after the government's stance towards the Kurdish issue shifted to a nationalistic tone in 2015, Amedspor started to receive frequent suspensions from the TFF. In the 2015-16, 2016-17 and 2017-18 seasons (until April), Amedspor was penalized 63 times by the TFF for various reasons. Fans were penalized 37 times, and star forward Deniz Naki (with Bundesliga and Süper Lig experience, who is among the best players of the division) received three suspensions of 12, 4 and 6 games respectively, before receiving a lifetime ban in January 2018, along with a record-breaking 273,000 Turkish Liras (65,000 USD) penalty for "ideological propaganda." In the full tally of penalties and suspensions given to Amedspor by the TFF (Table 1), the "ideological propaganda" penalties are exceptionally important. Amedspor were given this penalty 9 times as a club, along worth of a total pecuniary punishment of 280,000 Turkish Liras (67,000 USD, an important sum for a third division club), one match suspension and 3-point penalty. Deniz Naki was given this penalty twice, resulting in a 12-match suspension and 292,500 Turkish Liras pecuniary punishment.

If one has to take a look at the use of this "ideological propaganda" ban by the TFF, it will become apparent that this rule was applied exclusively against Kurdish clubs. Apart from Amedspor; Dersimspor, Van Büyükşehir Belediyespor (KPM-run municipality club), Diyarbakır Büyükşehir Belediyespor (KPM-run municipality club, former name of Amedspor), Cizrespor and Diyarbekirspor are the clubs having received this penalty. Meanwhile, the pro-government or anti-government slogans in the Istanbul stadiums, or the ultra-nationalistic slogans against the Kurdish teams never received this penalty. Even though it is not uncommon to see that anti-government or overtly racist slogans are penalized, they are usually handled under the "crowd disorder" category. Therefore, it is evident that the "ideological propaganda" penalty, which has been in place since 2014 , is only applied to the pro-Kurdish expressions in the stadiums. In a rare detailed explanation of the "ideological propaganda" penalty, the TFF stated in February 2016 that they penalized the "The barricade is here to stay; Everywhere is Sur, resistance is everywhere; Everywhere is Cizre, resistance is everywhere; Children should not die, they should come see our matches" slogans chanted by Amedspor fans.

Along with these suspensions and penalties, Amedspor fans often received away game bans for "security measures." According to sports columnist Nilay Yilmaz, fans born in Kurdish cities were banned from the Istanbulspor-Amedspor game in Istanbul in February 2017, and Amed fans were banned from away games in consecutive 26 weeks at that period. (Yilmaz 2017)

As of April 2018, Amedspor is trying to survive from relegation in Lig B. It continues to receive suspensions which create a financial burden, it has lost its star player, it is routinely deprived from away support. Also, after the Diyarbakır Metropolitan Municipality was taken over by the trustee appointed by

\footnotetext{
${ }^{2}$ The suspensions are listed on tff.org
} 
the Turkish government replacing the imprisoned elected officials in November 2016, the trustee demanded Amedspor to change its name and take government appointed municipality officials in the club board in order to continue receiving financial support from the municipality, however the club rejected both changes in early 2017 (Gazete Duvar 2017). In March 2018, the Ministry of Interior Affairs sent three inspectors to the club for thorough investigation, while the reason for the investigation was not declared to the club board.

\section{Discussion}

It can be said that the participation of the Kurds in sports activities in Turkey happens almost exclusively under the legitimizing identity attributed to them by the Turkish state, which is being Turkish citizens and in some cases a prospect or member of the Turkish national team. As long as their activities remain within the borders of this identity, it is not curbed, even encouraged. The World Youth Champion athlete Mizgin Ay, born in Batman, is a prime example of the use of this legitimizing identity. Mizgin Ay is a daughter of a Kurdish seasonal agricultural worker who was sponsored by the local authorities in Ankara where the family migrated. While Ay is Kurdish, her Kurdish identity is rarely visible whereas she is seen in press with the Turkish flag, almost without an exception. In the press interviews of Ay that we examined, only the Deutsche Welle (2017) interview mentioned that she is Kurdish, while the interviews in Turkish dailies mentioned the support of the Turkish officials (Hürriyet 26 July 2017; sozcu. com.tr 2017), her pride for the Turkish flag and national anthem (sozcu.com. tr 2017; Hürriyet 26 July 2017) and her homage to the slain Turkish soldiers (Habertürk 15 July 2017).

Meanwhile, the position of Amedspor in the identity scheme of Castells is up for debate. It is clear that the club, using a Kurdish name and Kurdish national colors, represents a resistance identity, openly contesting unwritten rules of Turkish sports, forcing the governing bodies to officially take action. Amedspor, while negotiating with governing sports bodies regarding its name and colors, did not succumb to embracing the legitimizing identity and continued to challenge the norms imposed by the Turkish state, the dominant power. Whereas its success was heavily curbed by suspensions and penalties, it has continued to exist in terms that entails a resistance identity. Also, after the Diyarbakır Metropolitan Municipality was taken over by the trustee appointed by the Turkish government replacing the imprisoned elected officials in November 2016, the trustee demanded Amedspor to change its name and take government appointed municipality officials in the club board in order to continue receiving financial support from the municipality, however the club rejected both changes in early 2017.

On the other hand, the Amedspor case can be analyzed within the frames of the project identity. While the identity that the club projects can be considered to be a resistance identity, its existence in its own terms evidently aims to change the position of Kurds in society. It should be noted that Amedspor is one of the 
very few examples that managed to exist in the popular culture world of Turkey without being forced to denounce its Kurdishness while it is being displayed as a resistance identity. The other example that comes to mind is the legendary singer Ahmet Kaya, who became a symbol of Kurdish political expression in the 1990s and later assaulted by his peers in an award ceremony and was self-exiled in Paris where he died in 2000. Even though there have been many other Kurdish singers in the mainstream music market, Kaya was the only one to display his Kurdishness as a resistance identity. While the case of Amedspor is comparable to that of Ahmet Kaya, it should be underlined that Ahmet Kaya mostly challenged unwritten rules individually while Amedspor also had to challenge some written ones, in a period when other written rules were challenged by the Kurdish political movement. Therefore, in our view, the Amedspor case is closer to be an example of project identity, since it has not only contested the identities imposed to it, but tried to set a precedent to other Kurdish institutions that would aim to make a dent in the set of rules restricting the visibility of Kurdishness in the social, cultural and political life of Turkey. This strategy may be compared to the admission of the Palestinian Football Federation by the FIFA in June 1998, which even predates the right to participate in general debate of Palestine in the United Nations. As in the Palestine example, the Amedspor case is logically tied to the greater political strategy, which is the "Democratic Autonomy Project" in this example. Therefore, the identity displayed by Amedspor without taking the political and legal contexts in account may be considered to be a resistance identity, while its role in challenging the status imposed to the Kurds by the Turkish state corresponds to a project identity.

A long-time strategy of the Turkish state vis-à-vis Kurdish sports has been encouraging the Kurdish youth to be involved in sports activities, as long as these activities are heavily monitored or even run by the state institutions, giving absolutely no space to any manifestation of the Kurdish identity. On the contrary, the activities are often associated with the Turkish army or the governorships under a heavy dose of Turkish national signs in display, as in the case of Mizgin Ay. In other words, Kurds are free to play as long as they do not play as Kurds. The legitimizing identity imposed by the Turkish state and society to the Kurds leaves very little room for recognition. In sports, this space is even narrower, all sportspeople are candidates for representing Turkey; an athlete like Ay should be a Turkish champion, her Kurdishness is irrelevant, even harmful to the sports' function of generating national pride. Amedspor, meanwhile, appears to be a direct contestation of the legitimizing identity, as while its existence is a combination of resistance and project identities. Politically, the relationship between Amedspor and the football's governing bodies is in line with the conflict between the Turkish state and the KPM, or the Turkish society and the Kurdish identity.

Popular culture, especially sports, is an overlooked, and often undermined field in scholarly research. However, more often than not, it plays an important role in identity building in underrepresented communities. In the Kurdish case, football is one of the first and few attempts of giving the resistance identity 
mainstream visibility. In a setting where the use of Kurdish names and traditional colours have been criminalized and/or prohibited, Amedspor emerged as a direct challenger of the society's written and unwritten rules regarding the Kurds, in a vastly popular area like football which has been historically dominated by nationalism in Turkey. The use of football as resistance identity has been a recurring theme in Turkey, as the Gezi Protests in 2013 were marked by the participation of thousands of Stambulite football fans. The Amedspor case, differing from the latter, also offers, at least, the hints of a project identity that aims to change the rules regarding the Kurds in football, and partly in general. Meanwhile, the emergence of this resistance identity in football is also linked to the later failed peace negotiations between the Kurds and the Turkish state, therefore it appears in a period where the legitimizing identity imposed by Turkey to the Kurds was being shifted by a project identity, based on the Democratic Autonomy Project. The Amedspor case is a very particular example, since it is a football club that emerged representing a resistance identity during a period when the actors controlling legitimizing and project identities were holding formal negotiations. Furthermore, the club continued to represent the resistance identity after the negotiations ended, while both the legitimizing identity and the project identity went through major transformations as the military conflict restarted. Therefore, even though it seems that the fate of Amedspor is completely linked to the peace negotiations, the club continued to exist, albeit in more difficult conditions, after the peace process failed, as football continued to be meaningful for the Kurdish population in the city. In that regard, in our opinion, it is important to conduct further research on the autonomous characteristics of popular culture items representing resistance identities with respect to other, more dominant, types of identities.

\section{REFERENCES}

Akkaya, Ahmet Hamdi and Joost Jongerden. 2013. "Confederalism and Autonomy in Turkey: The Kurdistan Workers' Party and the Reinvention of Democracy." Pp. 201-220 in The Kurdish Question in Turkey, edited by C. Gunes and W. Zeydanlioglu. Abingdon: Routledge.

Arhan, Faruk. 2001. Geri Pas: Diyarbakırspor’un 33 Yılı. Sî Yayınları.

Bostancioğlu, Adnan. 1993. “Taraftar ve Solcu Olmak.” Futbol ve Kültürü. Istanbul: Iletisim 241-250.

Bozarslan, Hamit. 1992. "Political Aspects of the Kurdish Problem in Contemporary Turkey." Pp. 74-89 in The Kurds: a contemporary overview edited by P.G. Kreyenbroek and S. Sperl. London: Routledge.

Calhoun, Craig J. 1994. Social Theory and Politics Of Identity. Cambridge: Blackwell.

Castells, Manuel. 2010. The Power of Identity. 2nd ed., with a new preface. Malden, MA: Wiley-Blackwell.

Celep, Ödül. 2018. “The moderation of Turkey's Kurdish left: the Peoples' Democratic Party (HDP).”

Turkish Studies. Published online: 18 June 2018. DOI: 10.1080/14683849.2018.1483195

Cizre Sakallığlu, Ümit. 1996. "Historicizing the Present and Problematizing the Future of the Kurdish Problem: A Critique of the TOBB Report on the Eastern Question.” New Perspectives on Turkey 14: 1-22. DOI: 10.1017/S0896634600006221 
Deutsche Welle. 2017. "Mizgin Ay: Babam Antrenmanlara Zorla Gönderdi" DW.COM. Retrieved April 19, 2018 (http://www.dw.com/tr/mizgin-ay-babam-antrenmanlara-zorla-g\%C3\%B 6nderdi/a-40428750).

Ergin, Murat. 2014. “The Racialization of Kurdish Identity in Turkey." Ethnic and Racial Studies 37(2):32241. DOI: $10.1080 / 01419870.2012 .729672$

Ernst, Nicole, Sven Engesser, Florin Büchel, Sina Blassnig, and Frank Esser. 2017. "Extreme Parties and Populism: An Analysis of Facebook and Twitter across Six Countries." Information, Communication \& Society 20(9):1347-64. DOI: 10.1080/1369118X.2017.1329333

Ersanl, Büşra and Halil Bayhan. 2012. "Demokratik Özerklik: Statü Talebi ve Demokratikleşme Arzusu." Pp. 203-250 in Türkiye Siyasetinde Kürtler edited by B. Ersanli, G.G. Ozdogan and N. Uncarlar. Iletisim Yayıncilık: Istanbul.

EuroMed Rights. February 2016. "Turkey - Human rights under Curfew." Retrieved on 27 July 2018 (https://euromedrights.org/wp-content/uploads/2016/06/Turkey-Human-Rights-Under-Curfewang.pdf)

Gazete Duvar. 18 February 2017. "Kayyımdan Amedspor'a: Adını değiştir destek olalım” Retrieved on 24 July 2018. (https://www.gazeteduvar.com.tr/spor/2017/02/18/kayyimdan-amedspora-adini-degistir-destek-olalim/)

Gökaçtı, Mehmet Ali. 2008. Bizim için oyna: Türkiye'de futbol ve siyaset. İletişim Yayınları: Istanbul.

Gürer, Çetin. 2015. "Aktörün Perspektifinden Demokratik Özerkliğe Bakmak: Kürt Siyasal Hareketinin Demokratik Özerklik Yaklaşımı." Mülkiye Dergisi 39(1):57-92.

Habertürk, 15 July 2017

Human Rights Foundation (İHD). 31 March 2016. "14/12/2015 - 02/03/2016 79 days of Curfew Cizre Review Report."

Hürriyet, 26 July 2017

Keyman, E. Fuat. 2016. "Rethinking the 'Kurdish Question'in Turkey: Modernity, Citizenship and Democracy." Pp. 75-85 in Toward New Democratic Imaginaries-Istanbul Seminars on Islam, Culture and Politics edited by S. Benhabib and V. Kaul. Heidelberg: Springer

Krämer, Benjamin. 2017. "Populist Online Practices: The Function of the Internet in Right-Wing Populism." Information, Communication \& Society 20(9):1293-1309. DOI: 10.1080/1369118X.2017.1328520

Milliyet, 13 April 1998 - 23 January 2014

Nairn, Tom. (2003). The break-up of Britain. Altona, Vic.: Common Ground Pub.

Navaro-Yashin, Yael. 2002. Faces of the State: Secularism and Public Life in Turkey. Princeton, N.J: Princeton University Press.

Office of the United Nations High Commissioner for Human Rights (OHCHR). February 2017. "Report on the human rights situation in South-East Turkey."

Özpek, Burak B. 2018. Paradigm Shift between Turkey and the Kurds: From 'Clash of the Titans' to 'Game of Thrones.' Middle East Critique 27, 43-60. DOI: 10.1080/19436149.2017.1415513

Saracoglu, Cenk. 2009. "'Exclusive Recognition': The New Dimensions of the Question of Ethnicity and Nationalism in Turkey." Ethnic and Racial Studies 32(4):640-58. DOI: 10.1080/01419870802065226

Sayar1, Sabri. 2016. "Back to a Predominant Party System: The November 2015 Snap Election in Turkey." South European Society and Politics 21, 263-280. DOI: 10.1080/13608746.2016.1170254

Sorek, Tamir. 2003. "Arab Football in Israel as an 'Integrative Enclave." Ethnic and Racial Studies 26(3):422-50. DOI: 10.1080/0141987032000067273

Sozcu.com.tr. 2018. “Liseli Mizgin, Tarladan Şampiyonluğa Koştu!” Retrieved 19 April 2018 (http:// 
www.sozcu.com.tr/egitim/liseli-mizgin-tarladan-sampiyonluga-kostu.html).

Spaaij, Ramón and Carles Viñas. 2013. "Political Ideology and Activism in Football Fan Culture in Spain: A View from the Far Left.” Soccer \& Society 14(2):183-200. DOI: 10.1080/14660970.2013.776467

Van Bruinessen, Martin. 1998. "Shifting National and Ethnic Identities: The Kurds in Turkey and the European Diaspora." Journal of Muslim Minority Affairs 18(1):39-52. DOI: 10.1080/13602009808716392

Van Bruinessen, Martin. 2005. "Kurdish society, ethnicity, nationalism and refugee problems." Pp. 35-61 in The Kurds: a Contemporary Overview edited by P.G. Kreyenbroek and S. Sperl. London: Routledge.

Yavuz, M. Hakan. 2001. "Five Stages of the Construction of Kurdish Nationalism in Turkey." Nationalism and Ethnic Politics 7(3):1-24. DOI: 10.1080/13537110108428635

Yegen, Mesut. 2009. "Prospective-Turks' or 'Pseudo-Citizens:' Kurds in Turkey." The Middle East Journal 63(4):597-615. DOI: $10.3751 / 63.4 .14$

Yılmaz, Nilay. 9 February 2017. "Futboldan Elinizi Çekin.” Fanatik.

Yüce, Mehmet. 2015. İdmancı Rublar. Istanbul: İletişim Yayınları. 